\title{
Integrity of the Apparatus of the State Officials in Corruption Eradication in Indonesia
}

\author{
Adensi Timonor ${ }^{1}$
}

\begin{abstract}
:
Paragraph IV of the Preamble to the 1945 Constitution of the Republic of Indonesia (herein after referred to the 1945 Constitution of the Republic of Indonesia) asserts that the objectives of the state of Indonesia are to protect all the Indonesian people and their entire motherland, to advance the public welfare, to develop the intellectual life of the nation, and to contribute towards the establishment of a world order based on peace and social justice. The law enforcement should be carried out with full determination, empathy, dedication, commitment and courage with the support from ideal legal substances and cooperative societies. The aim of this research is to examine the integrity of the apparatus of the state officials in corruption eradication in Indonesia. This study belongs to the category of the qualitative research design. The result of this study is given: Corruption occurs only if three things are met, namely: (1) there is a benefit or rent that can be shared (2) a public official who has the power facilitates the process of corruption in the context of allowing access to certain parties to the benefit, and (3) there are certain parties who perform bribery actions. The integrity of the state officials is based on the legal consciousness of the apparatus of state officials who later will raise collective consciousness of the law on the state administration agencies. This legal awareness is inherent in the behaviour and not in the law as a rule. Legal awareness will influence the legal compliance of the state officials resulting in collective legal compliance of the state administration agencies making the integrity of the state officials as a reflection of legal awareness and compliance of the state officials personally and institutionally which will help realize effectiveness in eradicating corruption.
\end{abstract}

Key Words: Integrity of Appratus, Corrucption, Indonesia

JEL Classification: D73, K12

\footnotetext{
${ }^{1}$ State University of Manado, Corresponding Email: adensi.timomor@gmail.com
} 


\section{Introduction}

Paragraph IV of the Preamble to the 1945 Constitution of the Republic of Indonesia (herein after referred to the 1945 Constitution of the Republic of Indonesia) asserts that the objectives of the state of Indonesia are to protect all the Indonesian people and their entire motherland, to advance the public welfare, to develop the intellectual life of the nation, and to contribute towards the establishment of a world order based on peace and social justice. Therefore, in order to achieve those objectives, Indonesia as a law state upholds human rights, guarantees equality of all Indonesian citizens in law and government, as well as is responsible to uphold the law and government without any exception. This provides an obligation for all state officials to make positive efforts for the development to realize the objectives of the state of Indonesia in the dream of becoming a law state and to minimize even to eliminate obstacles and threats that may undermine the achievement of the ideals of the Indonesian state enshrined in the state constitution of Indonesia as mentioned above.

A variety of attempts are made to eradicate corruption in the form of either prevention or prosecution. The initial steps have been made in the history of corruption eradication consist of the establishment of the Law on Corruption Eradication since 1971 as well as the Law No. 31 Year 1999, the Law No. 20 Year 2001 on Corruption Eradication which are currently enacted. Substantially, the existence of the Law on Corruption Eradication continues to be improved and perfected. Structurally, corruption eradication efforts have been made with the establishment and optimization of the performance of the functions of institutions that have been given tasks to eradicate corruption such as the establishment of the Corruption Eradication Commission (Indonesian: Komisi Pemberantasan Korupsi $(\mathrm{KPK})$ ).

Since the reform era, there have been various laws and regulations issued in the attempts to prevent and eradicate corruption as well as the establishment of institutions that can support optimal eradication of corruption, however, the existing instruments and legal instruments are not powerful enough or sufficiently effective to reduce deviant intentions and behaviour of the state officials not to act against the law. The present difficulty in fighting against corruption is also due to the factor related to the apparatus of the state officials. Vertical Institutions, Judiciary Agencies, Taxation Institutions, Immigration Institutions, Customs Institutions, Military Institutions and the like remain presumed as very corrupt institutions. According to the Indonesian Transparency, the judiciary agencies are the agencies with the highest level of initiatives to solicit bribes (100\%), followed by the customs (95\%), immigration (90\%) the National Defense Agency (Indonesian: Badan Pertahanan Nasional (BPN) (84\%), the police (78\%) and taxes (76\%). 
Some cases of alleged corruption that occur in several state agencies include, among others, alleged corruption towards the State Court Panel of Judges of Solo giving an acquittal to the nine corruption defendants. The Panel of the Judges gave the acquittal to the corruption defendants by diverting the criminal responsibility to the administrative realm. In relation to the demands of the Public Prosecutor (Indonesian: Jaksa Penuntut Umum) which proved true, the Panel of the Judges argued that the defendants of the corruption case could be released since the corruption deed was not a crime, for example in cases of alleged corruption in the procurement of medical equipment of Banjarnegara Regency in 2006 with the Director of PT. Dharma Mulia Multi Farina Semarang and Ary Gunawan the head of the Health Facilities and Personnel Department of Banjarnegara Regency as the defendants which amounted to Rupees 2.9 billion, the corruption case of Sri Sadoyo Hardjomigoeno Suparno the former Vice Regent of Karanganyar and Suparno the former Chairman of the Regional Parliament (DPRD) of Karanganyar who were accused of the corruption cases of the Regional Budget (APBD) from 2001 to 2006 budget which amounted to Rp 2.9 billion.

In relation to law enforcement, Rahardjo (2009) states that law enforcement essentially contain a substantial value, namely justice, and the law enforcement is based on its main pillars, i.e. determination and strong commitment of the subsystems related to the law enforcement. Law enforcement does not only involve intellectual intelligence but also spiritual intelligence. In other words, law enforcement should be carried out with full determination, empathy, dedication, commitment and courage with the support from ideal legal substances and cooperative societies. Based on the explanation above, the purpose of this study is to examine the integrity of the apparatus of the state officials in corruption eradication in Indonesia.

\section{Literature Review}

\subsection{Theories of Integrity}

Integration is literally derived from an English word "integration" meaning perfection or as a whole. In this context, integration is defined as a process of adjustment among the elements that differ from one another in the life of the society so as to produce a life pattern of the society having harmonious functions. To understand the meaning of integrity, the author cites the definition of integrity from the Great Dictionary of the Indonesian Language, namely the quality, nature, or circumstances showing coherent unity that has the potential and ability that exudes authority; honesty. Actions that are deviant and harmful to the public interest are actions that negate the rights of others, such as corruption, fraud, conspiracy and unfair competition. As a result of these actions, duty as a servant deviates from genuineness raping the rights of others. Our downfalls to the actions that are deviant 
and harmful to others are resulted from personality fragmentation. Personality encounters a total dysfunction.

\subsection{Micro - Theories and Macro - Theories}

Many experts expressing their view point of micro and macro integration or integrity. There are experts who are more dominant at the micro level such as Coleman (in Ritzer, 2007) who sees that in certain integration, the micro or individual level is a more decisive factor for at the macro level. There are also experts arguing the opposite, namely Tian Deffrey Alexander who assumes that to give priority at the micro level is a mistake by stating that the dominant integration is at the macro level and continues to influence at the micro level. A view that sees equal relationships and linkages between the micro level and the macro level is proposed by Allen Liska (in Ritzer, 2007) by using the model of macro phenomena that consists of: Aggregation or collecting individuals' properties to present groups' characteristics; Structural covering the relationships among individuals within a group; as well as Global covering important characteristics in a large group such as laws and language.

\subsection{Agency Structure Theories}

Piere Bourdieu (in Klitgaard, 1998) draws attention to the relationship between habits and fields. He sees a bridge between subjectivity within an individual and objectivity within a society. $\mathrm{He}$ used a perspective called "construcfiviststructuralism". He looked at how the objective structures in the form of language and culture shape human actions. Within the view, in details, he explains what perceptions, thoughts, and actions are. How humans understand and construct their world, without neglecting the perceptions and constructs that have been built which also serve as constrains at the same time. Humans are social beings who actively develop structures to their regular lives. In essence, habits are a mental structure serving as a bridge that connects individuals with their social world.

Anthony Giddens (in Klitgaard, 1998), proposes his theory concerning the integrity of the structure agents to introduce the theories of structurisation. Giddens focuses on repeated social facts so that Giddens' theories explain the dialectical relationship and the interplay between agencies and structures. Agencies and structures in Giddens' view cannot be separated and are two sides of the same coin. Agencies and structures is a double dual. Every social action requires structures and every structure needs social actions. Agencies and structures are intertwined each other and are inseparable in their practice or in human activities. 


\subsection{Corruption}

The word corruption originates from a Latin word corruptio or corruptus which are later adopted in many languages such as the English word "corruption", the Dutch word "corruptive" and the French word "corrupt". The word corruption used in Indonesia comes from the Dutch word "corruptive" (Andi Hamzah, 2009). In Indonesian, the words "tindak pidana korupsi" (criminal acts of corruption) are literally derived from the words "tindak pidana" (criminal acts) and "korupsi" (corruption). Juridical, the definition of corruption described in the Law No. 31 Year 1999 on Eradication of Corruption Act which replaces the Law No. 3 Year 1971 provides the following definitions of the criminal acts of corruption:

1. Article 2 states that: "any person who acts unlawfully to enrich himself/herself or another person or a corporation that can harm the finances or economy of the state".

2. Article 3 states that:

3. "any person who for the purpose of enriching himself/herself or another person or a corporation, committing abuse of authority, opportunities, or facilities that belong to him/her due to his/her position financial that may harm the finances or economy of the state".

4. Articles 5,6,7,8,9,10,11,12,13.

Other definitions of the criminal acts of corruption have been described in those articles that show the criminal acts of corruption in the articles of the Penal Code Bill (KUHP) which are then absorbed into the criminal acts of corruption.

The Law No. 31 Year 1999 on the eradication of corruption defines that corruption is: any person who acts unlawfully to enrich himself/herself or another person or a corporation that can harm the finances or economy of the state, shall be punished with life imprisonment or imprisonment for minimally 4 (four) years and maximally 20 (twenty) years and a fine of minimally Rupees 200,000,000.00 (two hundred million rupiah) and maximally Rupees 1,000,000,000.00 (one billion rupiah).

The elements in those articles consist of:

- every person

- who acts unlawfully

- $\quad$ acts to enrich himself/herself

- That can harm the finances of the state.

The impacts of corruption are also given by Arief (2000) that corruption is an act that not only can harm the state finances but also can cause economic losses to the people. Corruption is a very reprehensible act that most people curse and hate, which are not only the people and the nation of Indonesia, but also the community of other nations all over the world. 


\section{Research Methods}

This study belongs to the category of the qualitative research design. McMillan and Schumacher (2006:233) states that qualitative research is a study, which regards reality as a social, individual or group construction, draws or gives meanings to a reality by constructing it (reality is multilayer, interactive and shared social experience interpretation by individuals). According to Strauss and Corbin (2008:42), qualitative research is a type of research which findings are not obtained through statistical procedures or other forms of such computation. Qualitative research emphasizes more on in-depth data collection of some individuals or in a limited environment (Cozby, 2005:174). This study meets the characteristics specified in the definitions by McMillan and Schumacher (2006), Strauss and Corbin (2008), and (Cozby, 2005), so that the design of this study adapted the qualitative research design.

Patton (1990:40) mentions a number of characteristics in qualitative research, namely: (1) Naturalistic inquiry, i.e. studying the real-world situations naturally, without manipulation, and being open to whatever emerges; (2) Inductive analysis, i.e. going deep into details and peculiarities of the data in order to discover categories, dimensions, and relationships; (3) Holistic perspective, where all the phenomena investigated are understood as a complex system that is more than just the sum of its parts; (4) Qualitative data, i.e. detailed description, investigation/inquiry conducted deeply; (5) Personal contact and insight, in which the researcher has direct and close relationships with the people, situations and phenomena being studied; (6) Dynamic systems, i.e. paying attention to processes, regarding changes as something constant, and continuing to take place either individually or culturally as a whole; (7) Unique case orientation, i.e. considering each case as something specific and distinctive; (8) Context Sensitivity, i.e. putting the findings in social, historical, and time contexts; (9) Emphatic neutrality, in which the study is conducted in neutral ways to make it objective while emphatic at the same time; and (10) Design flexibility, in which the research design is flexible and open to adapt in accordance with changes that occur.

\section{Research Findings}

Corruption occurs only if three things are met, namely: (1) there is a benefit or rent that can be shared (2) a public official who has the power facilitates the process of corruption in the context of allowing access to certain parties to the benefit, and (3) there are certain parties who perform bribery actions.

Corruption cases are often done by public officials or political elite who have power, capacities and authorities giving them freedom to provide legality for the actions 
taken so that when the judicial process is done, the corruption then is indeed covered by the forms of legality they create resulting in the justification that their actions do not belong to the acts of corruption. It can be seen for example in the case of an acquittal given to a corruptor in North Sulawesi Province. The court seemed as if justifying the actions of corruption. Law enforcement officers that are supposed to be the main gate of law enforcement in the attempts to handle corruption, in the view of the researcher, indeed serve as the main entrance to the higher rate of corruption in Indonesia. The urgent issue is that the integrity of the law enforcement officers is reduced by the fact that corruption indeed happens in the institution. Such a condition, according to the researcher, indicates the need in a dual role of the law enforcement officers both as the actors and the parties who have to eradicate corruption.

Corruption that occurs in Indonesia is state culture corruption or corruption that has become a culture. The relationship between the three stakeholders that does not run ideally and leads to corruption turns out to keep occurring although there have been a variety of attempts made to eradicate corruption both from the legal and institutional substances.

State officials play an important role in realizing the ideals of the nation. It is explicitly stated in the Explanation of the 1945 Constitutions which states that what is very important in terms of governance and the life of the state is the spirit of state officials and government leaders. In order to rescue and normalize the national life as demanded by reformation, common visions, perceptions, and missions of the entire state officials and society are necessary. Those common visions, perceptions, and missions should be in line with the demands of conscience of the people expecting the establishment of the state officials capable of performing their duties and functions, carried out effectively, efficiently, free from corruption, collusion, and nepotism.

In order to create state officials that are free from corruption, collusion, and nepotism, the Law No. 28 Year 1999 on the State Administration that is Free from Corruption, Collusion and Nepotism which contain provisions relating directly or indirectly to the enforcement of the law against corruption, collusion and nepotism is specifically aimed at state officials and other officials having strategic functions in relation to the administration of the state in accordance with the provisions of applicable laws and regulations.

The regulation of public participation in the law is intended to empower the community to realize the state administration that is clean, free from corruption, collusion, and nepotism. With the rights and obligations that the communities have, they are expected to be more passionate about performing social control optimally 
towards the state administration while continuing to obey the legal guidelines (rambu-rambu hukum) of the applicable law.

The discussion on state officials in the view of the author is the discussion about something personal and institutional. Individuals and institutions are the two inseparable parts. The capacity of an individual will determine the quality of a certain institution and vice versa the quality of an institution will also determine the capacity of individuals within the institution. Corruption as a criminal action is attached to a person or individual and not to an institution. However, the discussion about individuals and institutions cannot be separated in discussing the issue of corruption. Furthermore, in the larger scope, individuals and institutions will be an integral part of the discussion about territory or regions. Thus, the high rate of corruption in a region will always be closely associated with the performance of an institution and individuals' capacity of the institution.

Ritzer and Douglas (2007) mention that there are four types of approaches in an attempt to integrate the micro level and the macro level, namely 1) the formulation of an integrated sociological paradigm, 2) sociology with a multi-dimensional paradigm, 3) the development of a model of "from the micro level to the macro level", and 4) integration through the micro basis to understand the macro aspects in an integrated sociological paradigm approach. Ritzer and Douglas view attempts to combine micro and macro levels using two different aspects, namely 1) from the micro level and the macro level, and 2) from the objective aspect and the subjective aspect. Both of these aspects have four dimensions: macro-objective, macrosubjective, micro-objective, and micro-subjective. The whole micro and macro social phenomena are also objective or subjective phenomenon.

According to Ritzer and Douglas, the relationship between personal issues at the micro level and public issues at the macro level is used to analyze the social world by not prioritizing one of the levels, but emphasizing the need to learn the dialectic relationship among these dimensions.

Another leader who expresses a view concerning the theory of integration is $\mathbf{J}$. Alexander who uses Ritzer's view point without imitating his analysis. Alexander does not put an emphasis on the micro and macro levels, but on the regularity issue. The level is neither the micro level nor the macro level, but individually and collectively. He focuses on the action that moves from a materialist to an idealist. Alexander puts more emphasis on the macro level. He thinks collective phenomena cannot be explained by describing how the phenomena at the micro level.

In the development of sociology associated with theories of interaction, a postmodernism view is expressed by Anthony Giddens known as the Theory of Structuration. He argues that structures and agencies are two different things which are also a unity (duality), where it cannot be learn separately from each other. 
Human beings through their activities can create awareness and structural conditions at the same time so that everyone's activities can be performed. It is impossible to have agencies without structures, and vice versa, there will be no interdependent structures if individuals do not create them.

The basic concept of the structuration theory lies in the ideas about the structure of the system and the dual nature of the structure. Structures are not reality outside an actor, but there are rules and resources manifested when activated by the actor in a social practice.

Each form of corruption eradication, both in the form of prevention and law enforcement actions, the role of the apparatus of the state officials is vitally necessary. In the form of preventative, the role of the government officials as the bureaucracy, the Regional Parliament as representatives of the people, academicians as intellectuals forming the characters of the younger generation, are very important in corruption eradication. However, in reality, corruption indeed occur among the state officials. This phenomenon needs investigation as social reality that shows a relationship between state officials and corruption.

Corruption in the branches of state power occurs not only in Indonesia as the view of Kaufmann and Paul (2002) that corruption taking place in all countries happens to the branches of state power as quoted as below:

- In the executive branch of government, the most common picture is that of a public official accepting or soliciting a bribe for the performance or nonperformance of an action associated with his or her office. Bribery, in the form of 'facilitation" payments, kick-backs, expensive gifts, etc. are at the center of "grand corruption" that may involve the privatization of large state assets, massive procurement contracts and the like to "petty corruption" that involves routine speed money, small bribes, etc. Usually, these types of corrupt practices are identified and prohibited by criminal statutes with corresponding sanctions. They also emerge at the interface of private and public sectors, as companies seek to either purchase state assets below market price or to deliver their line of business through contracts.

- Corrupt acts are practiced within the administrative domain. These include such behaviour as nepotism and cronyism based on a "spoils system," resulting from a pervasive politicization of the bureaucracy; ghost workers on public payroll; purchase of public offices; collection of unauthorized fees, falsification or the destruction of records; arbitrary administrative action and bending or circumventing established regulations. Thus, rather than the bureaucracy serving the public interest, the bureaucracy itself becomes an instrument for propagating the political interests of the leadership, its own 
self-interest, or the personal interests of those within it. These types of acts are generally prohibited by civil service and administrative procedures acts and regulations with administrative sanctions. In addition, some of these practices are also covered by the criminal statutes. Corrupt administrative practices, then emerge at the interface of the political leadership and the supposedly-neutral and professional public administration.

- Corrupt practices also manifest themselves in the legislative branch in many countries. Campaign financing has come under increasing scrutiny, especially unregulated "soft" donations in developed countries, as they are seen as an investment to influence future decision-making in the event that a party becomes elected. During elections, fraud and vote rigging also undermine democratic principles and the legitimacy of outcomes. Once in office, many elected officials become involved in influence-peddling, trying to obtain decisions to favour their own interests or those of the organizations with which or individuals with whom they are affiliated. The outcomes of these kinds of acts result in ethnic or regional favouritism, "boss" or "machine" politics, etc. Apart from laws regulating elections, it is more difficult to achieve a consensus around the prohibitions and sanctions against these types of activities. There are ethics legislations and conflict-ofinterest policies that cover them. These types of corrupt acts occur at the interface between political parties or their membership and the private sector as well as various interest groups or influential individuals.

- Corruption is particularly pernicious in the judiciary, an institution that is supposed to uphold the rule of law. In some cases, judges extract bribes not only for delivering a verdict in a predetermined way but even for merely hearing a case. Lower order court clerks can also solicit bribes for producing or hiding certain information that is crucial to cases. The independence of the judiciary itself can be undermined by the executive branch influencing the appointment and promotion of judges. In such situations, judges are pressured to reach verdicts not based on justice but on political expediencies.

The views expressed by Kaufmann and Paul above shows that corruption indeed occurs among state officials, either the executive, the legislative, academicians even law enforcement officials. In their view, corruption can only occur if a particular person or party has a monopoly on certain matters which is also supported by discretion or flexibility in the use of power, so the person or party tends to abuse it; however the person or party is weak in terms of accountability to the public. 
In an international scale, the indicators for integrity according to USAID are:

\section{a. Accountability}

Accountability is intended to regulate mechanisms to ensure that the institutions and apparatus faithfully perform their duties to the public, private sectors, and other stakeholders. Accountability works in the relationship among public officials, namely behaviour and performance on the one hand, and reward and punishment on the other hand. It can be seen in three layers: between voters and politicians, between politicians and bureaucrats and between supervisors and subordinates of public officials. In so doing, accountability is carried out through surveillance systems and internal controls within state officials, as well as through interactions with civil society which improve external supervision and thereby strengthen the responsibilities of institutions and public officials to respond to the interests of other stakeholders. Horizontal accountability refers internal supervision and external investigation, and other actions undertaken by the authorities such as auditors and ombudsmen (or legislative committees) to other government agencies. Vertical accountability is an examination performed by actors outside the state.

\section{b. Tranparancy}

Transparency is the ability of citizens, public officials and civil society to access information materials they need to make decisions and the accountability of public sector agencies. Public sector agencies include public institutions and organizations, and officials whose missions are to create, implement, and enforce the official rules of the game, provide and allocate public goods, and collect and spend public funds. The actors include stakeholders whose customers, users, and intended beneficiaries of public institutions and organizations. Substantive transparency is the dissemination of information from public sector agencies to the actors of private sectors most directly interested in the service agents. Procedural transparency refers to an attempt to open an inclusively and participatory process (e.g., freedom of information and clarity of the law) so that political actors and civil society can influence the official rules of the game, the provisions and distribution of public goods, and the expenditure of public funds)

\section{c. Prevention}

Prevention is efforts made by an agency or organization to reduce the opportunity to perform corruption. It includes reducing monopoly and policies, civil service, separating private and public actors, and formalizing public-private relationships. It also includes identifying and eliminating bad incentives by facilitating competition, services, and living wage. Thus, restructurization to prevent the removal of unilateral decisions, promote competitions and choices, issue uncontrolled policies from public 
officials, and replace anything arbitrary, ambiguous, complex, and determine objectives of the standard rules and modify by sacrificing flexibility for simplicity, certainty, and uniformity of application.

\section{d. Enforcement}

There needs to be an incentive to comply with the rules of accountability. Effective enforcement usually requires administrative sanctions for negligence, poor or imperfect performance, as well as criminal penalties for corruption. Enforcement can be implemented by the government and private actors (civil society, supervisors, independent media, private companies, and individual citizens protesting the government's inappropriate decision).

\section{e. Education}

The dimensions of awareness, advocacy and values can be promoted through, the government and the private sectors. Education realizes the identification, dissemination and institutionalization of values and standards related to ethical behaviour that reduces tolerance to corruption and promotes integrity in the public and private sector relationships. Ethical standards motivate public officials to avoid corrupt behaviour, even when they are driven by the simple calculation of costs and benefits. Education involves attempts to change behaviour through public communications that advocate certain reforms, and raise awareness about the characteristics, causes, dynamics, and consequences of corruption.

Those five indicators of integrity above are conditions to realize good state administrators to support the eradication of corruption. The five indicators above, according to the researcher, cover all activities of state officials, namely accountability, transparency and education, comprise indicators for the performance of duties and functions of state officials to prevent the occurrence of corruption and law enforcement are indicators for the prosecution of corruption criminal actions. The five indicators can also involve all stakeholders in the development to work together to prevent corruption among state officials in all powerful functions of either in the executive, the legislative and the judicial branches, private sectors and the public.

The apparatus of the state officials are parts that cannot be separated from the state administration agencies making the ways of thinking and behaving as well as ethics of the apparatus of the state officials is also determined by the integrity of the state administration agencies both internally and externally. Therefore, the researcher assumes that the efforts to eradicate corruption should be done with penal and nonpenal facilities involving three main actors, namely individuals, state officials and the public and corruption eradication can only be done if all the three actors are in 
one integral unity that is supported by laws and regulations serving as a reference in the integrity of the state officials. The concept of eradication of corruption is summarized by the researcher as a circle of integrity moving from the individuals to the public or which the researcher refers to as the circle of integrity as seen in the picture below

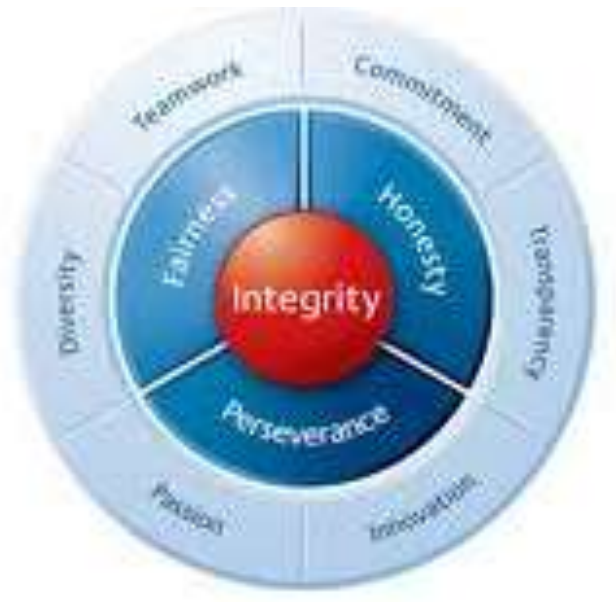

Figure 1: The Circle of Integrity

The picture above is a summary of the anti-corruption strategies in the view of the researcher. In the picture above, ethics and morality become a basis for both personal and institutional integrity. An effort to create institutional mechanisms that have legal and consistent patterns requires legal substances. Integrity among the apparatus of state officials, state administration agencies and the public as well as the integrity between ethics and morality with the legal substance can be used as one way of eradicating both corruptions through penal and non- penal facilities.

Muladi (1997) argues that the dimensions of law enforcement which should be highlighted are the aspect of professionalism that prioritizes skills through intensive exercises, a sense of social responsibility and adherence to ethics. For your information, the profession of law enforcement in terms of the ability not only contains physical skills, but also requires a significant intellectual component. Professional attitude will keep the din of mal-practice actions in the area of law in the forms of actions that are below the standards, contrary to the obligations.

The necessary characteristics of law enforcement agencies are having the maturity value/ psychology, which will be able to renourish moral values and ethics in law and law enforcement, their relationship with the criminal law, as a new generation in the development of criminal law. In this case, Satjipto Rahardjo introduces the need in a new generation of thinkers and legal actors in Indonesia, which are capable of designing, making, applying the law to bring justice to the people. 


\section{Conclusion}

The integrity of the state officials is based on the legal consciousness of the apparatus of state officials who later will raise collective consciousness of the law on the state administration agencies. This legal awareness is inherent in the behaviour and not in the law as a rule. Legal awareness will influence the legal compliance of the state officials resulting in collective legal compliance of the state administration agencies making the integrity of the state officials as a reflection of legal awareness and compliance of the state officials personally and institutionally which will help realize effectiveness in eradicating corruption.

\section{References}

Arief, B. N., (2000), "Fundamental Principles of the Supremacy of Law: An Aspects of a Judicial Study, Seminar Paper, Faculty of Law, Diponegoro University

Busse, L., (1996), "The Perception of Corruption: A market Discipline Corruption Model", Goizueta Business School, Emory University, Atlanta, Georgia U.S.A.

Cozby, P. C., (2005), "Methods in Behavioural Research", McGraw-Hill Company Inc., New York.

Darwin, P., (2002), “The Criminal Action Eradication of Corruption”, Citra Aditya Bhakti: Bandung.

Hamzah, A., (2009), "The Corruption Eradication through the National and International Penal Code”, 5th Ed. Raja Grafindo Persada, Jakarta.

Jaya, N. and Serikat P., (2005), "The Criminal Actions of Corruption, Collusion and Nepotism Indonesia”, Diponegoro University Press, Semarang.

Kaufmann, D. and Siegelbaun P., (2002), "Combating Corruption for Devolopment, the Rule of Law", Transparancy and Accontability.

Klitgaard, R., (1998), "Eradicating Corruption”, Obor Foundation, Jakarta.

Lopa, B., (1983), "Corruption Crime and Law Enforcement”, LP3S, Jakarta.

Muladi, K., (1997), "Human Rights, Politics, and the Criminal Justice System", Diponegoro University Press, Semarang.

Mulyadi, L., (2000), "The Criminal Actions of Corruption, a Special Study to the Processes of Investigation, Prosecution, Judiciary and Its Legal Efforts in Accordance with the Law No. 31 Year 1999", Citra Aditya Bhakti, Bandung.

McMillan, J. H., and Schumacher S., (2006), "Research in Education", Pearson, New Jersey.

Patton, M. Q., (1990), "Qualitative Evaluation and Research Methods", Sage Publications, New Delhi.

Rahardjo, S., (2009), "Law Enforcement: A Sociological Study”, Genta Publishing, Jakarta.

Ritzer, G. and Goodman, D. J., (2007), "Modern Sociological Theory”, Kencana. Jakarta.

Strauss, A. and Corbin, J., (2008), "Basics of Qualitative Research", Sage, Los Angeles.

USAID. (2005), "Tools for Assessing Corruption and Integrity in Institutions", Iris Center. Maryland University. Him. 